\title{
Islamic Muslim Brotherhood Scholars and “Arab Spring" in Palestine
}

\author{
Shaul Bartal \\ Department of Middle Eastern Studies, Bar Ilan University, Israel
}

Copyright $@ 2015$ Horizon Research Publishing All rights reserved.

\begin{abstract}
This article shows the connections between three subjects --the "Arab Spring," Yusūf al-Qaraḍāwī and Hamās and their war against Israel. The recent upheavals in the Arab world commonly referred to as the "Arab Spring" have elicited reactions on the part of various Islamic figures. The most important of these is Sheikh Yusūf al-Qaraḍāwī, the leading Islamic scholar and the spiritual leader of Hamās. Al-Qaradāwī supports the revolutions and regime changes by the Muslim Brotherhood. He bases his views upon the teachings of Sayyid Quț, the paradigm of Takfir. According to Sayyid Qutb, societies that don't behave according to Islam are infidel societies. This includes secular rulers like Husnī Mubrak and Múammar al-Qadhāfì. Therefore, they must be replaced by a truly Islamic society. According to al-Qaraḍāwi , the Arab Spring period is the for that type of replacement. Hamās, as presented by Khālid Abū Arfa and others, is the organization that should benefit from the Arab Spring revolutions. The Islamic revolutions and the new Islamic regimes in Tunisia, Egypt and others can help Hamās in the way of $j i h \bar{a} d$ against Israel. The Pan Islamism of the Muslim Brotherhood could be also harbinger of the state of Israel.
\end{abstract}

Keywords Al-Qaraḍāwī , Hamās, "Arab Spring", "Muslim Brotherhood", Sayyid Quṭb, Khālid Abūarfa, Islam, Revolution, Jihād

\section{Islamic Law and Secular Rulers}

Islamic scholars struggle to understand modern-day Muslim rulers who do not conduct themselves according to sharīa principles and Muslim rulers who adopt foreign and secular norms of governance such as western democracy, eastern European socialism and communism. The views of Sheikh Yusūf al-Qaraḍāwi , head of the International Union of Muslim Scholars (IUMS), a popular preacher on Al-Jazeera and a member of many Muslim organizations, do not differ from other Muslim Brotherhood figures such as Hassan al-Huḍaibi, Sayyid Quṭb, Abū Ala al-Mawdudi and others who have written extensively on this topic. Sayyid
Quțb's works serve as Qaraḍāwī 's major source of inspiration, particularly for his treatment of the problem of takfir -- the Islamic attitude toward a Muslim society that is, for all practical purposes, secular.i

Takfir is described in detail in Sayyid Quṭb's well-known book Maālim fil-Tarīq (Milestones or Signposts on the Road). This book presents a sober analysis of the idea of a new jāhiliyya (the pre-Islamic period of paganism and ignorance) where only the rule of Allah, al-häkimiyya, is the true government according to sharīa. Quṭb clearly defines what constitutes a jāhiliyya society:

"The Jāhili [sic] society is any society other than Muslim society. And if we want a more specific definition, we may say that any society which does not dedicate itself, in its beliefs, to submission to Allah alone, is a Jāhili [sic] society. According to this definition, all of today's societies worldwide are Jāhili" ii

Quṭb further states that Muslim societies, such as Egypt under Nasser and his successors, are jāhiliyya societies:

"We classify them among Jāhili [sic] societies not because they believe in other deities besides Allah or because they worship anyone other than Allah... Although they may believe in tawhīd (monotheism), still they have relegated the legislative attribute of Allah almighty to others and submit to their authority and from this authority they derive their systems, their traditions and customs, their laws, their values and standards and almost every practice of life."iii

Quṭ's idea of the new jāhiliyya implies that secular societies in Arab countries exist in a state of ignorance similar to that what prevailed prior to the revelation of Islam and Muslims are obligated to re-establish Islamic society. Qutb message of hate toward secular rulers and the right to rebel against them in order to establish a just and true Islamic regime was presented in his book, Our War with the Jews, originally published in 1954. Quṭb expressed his hatred toward the government of the Free Officers and referred to them as "Black Englishmen." They look like Arab Muslims but conduct themselves like English colonialists. Quṭ 
promises the people that:

"Your day will come and your opportunity will arrive. [It will be] the day when you will throw the White Englishmen beyond the borders and you will establish popular courts for the Black Englishmen. And we will put those on trial who have "honored" you with fear, hunger and loss of property, valuables and crops. Thus, it will be proclaimed to those who are patient (sāairīn): 'Those who have been afflicted by a catastrophe and said to God: "We are yours and we are returning to you." " I shall dedicate my prayers to them before their Master and [there will be mercy] from Him. They are those who have been instructed in the right path"iv

Many years later, Sheikh Qaradāwī similarly called the army officers led by General Abdul Fattah al-Sisi, "army dogs".v Like Quṭb before him, Qaraḍāwī adopted the idea of the hākimiyya, the sovereignty of God as a key concept.vi Qaraḍāwī 's statements include a fatwa to kill Muhammar al-Qadhāfí vii and a fatwa to stone Mahmoud Abbas for his cooperation with Israel during Operation Cast Lead in Gaza (27/12/2008-17/1/2009).viii This type of fatwa constitutes a direct continuation of Qutb's idea of takfir which maintains that secular rulers of Muslim societies should be viewed as infidels deserving of the death penalty.ix This attitude was not typical to Qaradāwi in the past because he firm condemnation of the attacks of radical Islamist against secular governments. $x$

The justification of al-Qadhāfî's death under his fatwa was the indiscriminate slaughter of his own people and his unprecedented crimes beyond those of any secular ruler. In contrast, Qaradāwī has not issued a fatwa permitting the killing of either Bashshār al-Assad or Abd al-Fattāh al-Sīsī, despite his disapproval of their regimes and his desire to see them fall.xi

Qarad̄āwī distinguishes between a backsliding Muslim ruler whose regime must be opposed and the Muslim public. He maintains that those who consider Muslims that act differently than from themselves as infidels are mistaken and simply do not understand the works of Sayyid Qutb. According to Qaraḍāwī 's interpretation of Sayyid Quṭb, the term "the new jāhiliyya," invented by Quțb, refers specifically to the regime and the ruler and not to members of the Muslim community. Qaraḍāwi also contends that it is possible to understand the origins of the broader interpretation of Qutb's idea of takfir on the part of Muslim Brotherhood activists.

Qaraḍāwī supports the overthrow of governments and voices criticism against the secular rulers by openly opposing their regimes. Any public deviation from Islamic norms on the part of the rulers, such as adopting a Western life style of laws, is considered heresy whose punishment is death. Heresy on the part of a Muslim ruler, such as Gammāl Abd al-Nāșir, Husni Mubārak, Muammar al-Qadhāfī or Mahmūd Abbās means their "joining the enemies of God in order to act against the friends of God".xii. Sayyid Quț's legacy of political Islam successfully enables Hamās to portray all Palestinian secular opposition as part of the modern Jāliiyya and as such obstacles to the acquisition of a free Palestinian state.xiii

According to Khālid Abū Arfa, the sin of Al-Qadhāfī "was that through his deeds he joined the enemies of the Umma and recruited regiments of mercenaries in order to injure civilians".xiv Thus, Qaraḍāwī is justified for issuing a fatwa to kill Al-Qadhāfí. AbūArfa is a well-known Hamās activist. He was born in 1961 in Silwan/Ras al-Amud East Jerusalem. Graduate of machine engineering studies at Baghdad University. A trustee of the Nun Center for Quranic study and research. Member of the committee for protecting land and property in Silwan/Ras al-Amud. He was arrested by Israel on June 29, 2006 after the kidnapping of Gilad Shalit on behalf of his membership in the tenth Palestinian Government. On June 4, 2010 there was issued against him a restraining order to leave Jerusalem and on August 12010 he and his mates fled to the offices of the Red Cross in protest. In January 2012 he was arrest and December 2014 was convicted for membership in terrorist organization and illegal stay in Israel. Eli Yishai's opinion, former minister of interior affairs, was accepted in a forum of nine judges. In Operation Brother's Keeper (May 2014) he was arrested for an additional three months. Currently he lives in Ramallah and his family is active in the Temple Mount and Hamas Jerusalem.

Muslim public opinion (the Muslim conscience led by scholars, preachers and thinkers) demands opposition to backsliding Muslim rulers. The arguments by Qaradāwī , and Quț,xv before him, may be understood as supporting armed struggle against such rulers, led by independent thinkers, if necessary. xvi This is the background for understanding Qaradāin̄ 's position in regard to the events that are referred to as the Arab Spring.

\section{Qaraḍāwī 's attitude toward the "Arab Spring”}

Muhammad Bouazizi, a 28-year old from of Sidi Bouzid, Tunesia, set himself on fire on 17/12/2010. His subsequent death led to a wave of protests against rulers in many Arab countries. On 14/1/2011, the president of Tunisia, Zine El Abidine Ben Ali, was forced out. The Al-Nahda (Renaissance) Party received $41 \%$ of the votes in the national elections that were held later that year and became the ruling party. Its leader, Rashīd al-Ghannūshi, represented the local branch of the Muslim Brotherhood. Revolutions in other Arab countries followed. The outstanding examples were Libya and Egypt. In Libya, the regime of $\mathrm{Mu}^{\mathrm{c}}$ ammar Al-Qadhāfī fell. In Egypt, President Husni Mubārak left office in disgrace after ruling for thirty years. The revolution of 15/1/2011 brought about the end of Mubārak's rule and the accession of the Muslim Brotherhood.

In 2013, there were further changes in the Arab world. The most important was the counter-revolution led by General Abd al-Fattāh al-Sīsī against the Muslim Brotherhood and their elected president Muhammad Mursi. In addition, the Shiite-Sunni split grew as a result of the public entry of Hezbollah into the Syrian conflict on the side of Bashshār 


\section{al-Assad.xvii}

Over the past three years, Sheikh Yusūf Al-Qaradāwī , from his home in Qatar, has encouraged the Muslim Brotherhood all over the Arab world to play an active role in ousting "infidel" rulers and taking power. According to Qaradāwī , after the abolition of the Caliphate and the expulsion of the Colonial rulers, the Islamic umma suffered an additional blow from the subjugation by rulers who were nominally Muslims but did not live according to Islamic law. These rulers were exposed as unbelievers and as greater offenders than the Colonialists.xviii Al-Qaradāwī , in his program on Al-Jazeera, "Al-sharīa wal-Hayāt," emphasized the legitimacy of the representatives of the Muslim Brotherhood parties -- Al-Nahḍa in Tunisia and Al-Huriya wal-Adl (Freedom and Justice) party in Egypt - which were elected democratically. In addition, he did not hesitate to pronounce death sentences against Muammar Al-Qadhāfī or call for jihād against the Syrian regime that slaughtered its Muslims aided by Iran and Russia.xix

In order to ensure the success of the Arab revolutions, Qaraḍ̄̄ī exerted his great religious and political influence. Qaraḍāwī believed that these upheavals would lead to the revival of the Islamic umma as "one people, one religion, and one language". xx Delegations from Tunisia, Morocco, Yemen, Libya, Syria and Palestine made pilgrimages to Qaraḍāwī and received his blessing and financial support. As head of IUMS, Qaraḍāwī functions as the most influential spiritual leader of the Sunni "Islamic ummah." In a sermon delivered on 10/5/2013 at the Great Omari Mosque in Gaza, Qaraḍāwī explained that all of the Arab peoples will be victorious if they believe in Allah and will be united in their belief. Qaradāwī ended his sermon by blessing the Palestinians, as follows:

"In the name of your Muslim brothers from Egypt, your brothers from Syria, your brothers from Tunis, your brothers from Libya and your brothers in the Maghreb, your brothers from Yemen and your brothers from Somalia, your brothers from Pakistan and your brothers from Bangladesh, and your brothers, the holy warriors everywhere ..."xxi

According to Qaraḍāwī, all the events of the Arab Spring, such as the fall of secular regimes in Egypt, Yemen, Tunisia and the riots in Syria and other Arab countries, are part of a global struggle that will end when the faithful of the Muslim umma will rule over a single Islamic state.

The Muslim Brotherhood views the Islamic revolution of the past three years (2011-2013) as the fulfillment of the way of Hasan al-Banna:

"This Arab homeland that extends from the Persian Gulf to Tangier, along the length of its lands and the width of its territories, [there is] a geographical unity that is divided neither by natural barriers nor by mountain ranges ... this homeland constitutes a linguistic unity by dint of the language of the Arabs and the dispersion of their fighting sons who sanctify it in their prayers and the book of God perpetuates it through signs and wonders ..."xxii

Like al-Banna, Qaraḍ̄wī also preached for the unity of the Arab homeland. He maintained, as early as 1968, that it was a separation from Islam that led to a schism between the people and the authorities. Secular rulers such as the Bath, Nasserism or socialists followed a secular ideology while the masses leaned toward Islam.

For Qaraḍāwī , it was the Egyptian government, a secular regime, which was the party responsible for the nakba of 1948 and the defeats in 1956 and 1967. Since secular governments failed to solve the problems in the Arab countries, it became clear that Islamic rule must replace them.

While Qaradāwī speaks in general terms, his statements are influenced by events in Egypt. In the past, before people believed in secular ideologies, all were brothers and shared a common faith and common goals. Secular philosophies arose and created divisions in a unified society and even within the same family. Factions and groups were, founded that only cared about themselves whereas Islamic society must be one society that acts out of common values with a single sharīa. xxiii For Qaradāwī , the Arab Spring represented the opportunity to take down secular, infidel governments in the spirit of Sayyid Quțb. Qaradāwī 's poems, replete with religious anger and fervor, encouraged young people to go out and demonstrate against the authorities.xxiv

In 2011, Khālid Abū Arfa, former Minister for Jerusalem Affairs in the Hamās government set up by Hamās after the elections of 2006. He presented the views of faithful Muslims toward the recent upheavals in Arab countries in his book: Revolutions Herald a New Dawn: From the Standpoint of Islamic Law (Jerusalem, without a name of a publisher, 2011). His pro-Hamās views are based upon the articles and books by Sheikh Yusūf al-Qaraḍāwī . Abū Arfa 's conclusion links the revolts of the Arab Spring to the Palestinians and to the future of Israel. He quotes from the fatwa published by the Committee of Islamic Scholars of the Islamic Action Front (the branch of the Muslim Brotherhood in Jordan): "Support for the struggle against a tyrant is a religious obligation of sharīa".xxv

According to Qaraḍ̄ī $\overline{1}$ and the IUMS, the mass demonstrations are an expression of the Muslim rejection and condemnation of existing Arab governments for their totally unconscionable and reprehensible acts:

"The demonstrations [in Arab countries] attest to the solidarity which exists among the Arab and Islamic peoples who are fighting a Holy War against the infidel leaders in Tunisia, Egypt and elsewhere. God will give us victory over the leaders of the heretics, by showing mutual help, honesty and fear of God."xxvi

Abū Arfa refers to Qaradāwī 's fatwa that encourages the masses to go out and demonstrate against the secular rulers and justifies their removal. The demonstrations which 
brought the Muslim Brotherhood to power are clearly described as one of the forms of jiha $\bar{d} d$ and that participation in the demonstrations in all of the Arab countries constitutes a religious obligation. Abū Arfa writes as follows:

"Going to demonstrations which demand the removal of the American and other military leaders from Islamic countries is a matter of representation. We are speaking of one of the definite forms of jihād and the resistance energizing it on the part of the dominant [Arab] street. [This is] just like the fatwa regarding the demonstrations that require support by Islamic peoples against the Crusader occupation and vanity in Iraq, Afghanistan and the Russians in Chechnya. We must consider this a religious matter and one of the forms of jihād."xxvii

Abū Arfa also regards demonstrations on behalf of the Palestinians of Gaza and the Hamās government area as another form of jiha $\bar{d}$ and not only as demonstrations calling for a regime change. As far as the Palestinian context is concerned, heretical leaders also include the Palestinian Authority as it collaborates with Israel and the United States:

"I say that the demonstrations that demand the removal of the evil siege of the Palestinians in Gaza and the repudiation of the heretical leaders who collaborate with the evil siege are bringing about the fulfillment of a splendid jihād."xxviii

\section{Qaraḍāwī and the revolution in Egypt}

On 25/1/2011, Hosni Mubarak was forced to end his term as president and an interim government, headed by General Țanțāwi, took over for a transition period until democratic elections were held. Election results gave the Muslim Brotherhood 127 seats and the Salafist party, Nur, 96 seats. As there are 332 seats in the Egyptian parliament, the Muslim Brotherhood became the largest party. xxix Al-Qaradāwī called upon all Egyptians, including those who opposed the Muslim Brotherhood, to show tolerance and respect for the democratic process, the election of Muslim Brotherhood representatives and the president. In a report that appeared on his website on February 2012, Qaradāin̄ referred to the demonstrations by secularist groups against the success of the Islamic parties, as follows:

"The elections in Egypt are proof that despite the fact that the Egyptian army has been strengthened and has seized power in the wake of the fall of Mubarak, the representatives of the army have not managed to convince the masses to support the secular candidates." $\mathrm{xxx}$

Qaraḍāwī was suspicious of the Egyptian army even before Abd al-Fattāh al-Sīsī's takeover:

"On the Friday when Mubārak fell from power, the process of the strengthening of the Egyptian army began and [it] has not stopped since then....During the elections they harassed the overseers and inspectors about the future of Egypt. What the supporters of the army desired was that there would be a special situation which would grant them an advantage over the others. They separated [themselves] from the main stream of the people because they do not accept the independence of the liberators of Egypt."xxxi

As far as Egypt was concerned, Qaraḍāwī was certain that the Egyptian people wanted a change after the sixty years of the dictatorships of Nāṣir, Sādāt, and Mubārak:

"Behold! After this entire period and through democratic and free elections, in the freest way possible, the people elected Dr. Muhammad Mursi. Although he was elected by a majority of 51 percent, the elections were free, clear and without any type of complaint."xxxii

Qaraḍāwi is full of appreciation for Muhammad Mursi:

"Mursi passed a constitution to which the nation agreed ... with 62 percent of those eligible to vote in Egypt giving their consent to the Constitution of the Muslim Brotherhood....Mursi brought freedom to the Egyptian people."xxxiii

For many writers, this Islamic revolution was the embodiment of the words of Islamic scholars such as Khālid Abu Arfa, who wrote: "The people rose in revolt against the rule of evil and corruption of Egypt's President Anwar Sādāt in 1981 and killed him."xxxiv This may be interpreted as meaning that Sādāt's murder was not due to his making peace with Israel but also because he was an evil and corrupt ruler. The new Islamic revolution of 25/1/2011 was considered a continuation from the phase of the death of Sādāt.

Qaradāwi î tried to strengthen the position of President Muhammad Mursi by visiting Egypt to take part in pro-Mursi demonstrations. But this visit did not take place due to the secular counter-revolution of General Abd al-Fattāh al-Sīsī in early July 2013.xxxv General al- Sīsī counter-revolution brought about a drastic change in Qaraḍāwī 's pronouncements regarding Egyptian rulers. Muhammad Mursi was called the "elected president" while General al-Sisi was a "rebel." As early as August 2013, Qaradāwī referred to al- Sīsī and his fellow officers as "army dogs".xxxvi In his program, Al- sharīa wal-Hayāt, presented in late December 2013, Qaradāwī stated as follows:

"The soldiers of the revolution are murderers and terrorists, and Allah is great, a God of vengeance. [He] lists all of their crimes and the exploitation by which they exploit the public, and the vengeance of Allah will certainly come ... and those who say that the Brotherhood is a terrorist organization? You, men of the army, you are murderers and terrorists ... a soldier is forbidden to rule over a civilian - [he does so] only during a period of tyranny and since the men of the 
army got rid of King Fārūq (the Officers' Revolt of 1952), they have corrupted political, economic, social and religious life in Egypt."xxxvii

Today, Qaraḍāwī continues to defend Muhammad Mursi and the revolution of the Muslim Brotherhood. According to him, Mursi is still the president of Egypt and General al- Sīsī and the rest of the current ruling party in Egypt are illegitimate and illegal. The demonstrators who died for Mursi are shahids (martyrs) who fulfilled their religious duty. xxxviii Al-Qaraḍāwī , however, remains strong in his convictions that the day will come and there will be a reversal of fortune:

"Mursi is a righteous man, his justice and his Islam angered Zionism and the enemies of Islam [a hint at Sīsī]. O Sīsī! O Biblawi! O Mansur! O Tartur! [The latter means "rascal" and rhymes with Mansur.]. On Judgment Day, Allah will ask you, who killed these people? Beware of Allah! Beware of Allah!"xxxix

Qaradāwī rejects anyone who presents a different religious position than his own, including his leading opponent, Ali Guma a, the former Mufti of Egypt who supports al-Sīsī's military rule in order to avoid civil war and needless bloodshed. Qaraḍāwī angrily dismisses Sheikh Guma a. He believes that the revolution led by the Brotherhood was a peaceful revolution and demonstrators were shot without any justification. Qaradāwī denigrates Guma a refers to him as a bureaucrat who completed his role as mufti and who has no authority at present. He claims that Sheikh Ali Guma a true Islamic scholar but only someone who possesses a modicum of knowledge from his studies. "He is one of the servants of the regime and a collaborator with the police. They tell him to say something and he does it..."xl Al-Qaradāwī also critiques the behavior of the current Sheikh of Al-Azhar, Ahmad al- Tayyib, who did not oppose al- Sīsī. He calls his behavior a shame on Egypt, despite his high status throughout the Islamic world.xli

From the fall of Mubārak until the present, Qaradīwī has been intensely occupied by the question of who is to blame for the counter-revolution and the failure of the "Islamic Revolution." Naturally, he blames the Jews and the United States. It is America and Israel who schemed and plotted in order to prevent the success of the Islamic movements in the Arab countries. "America and Israel do not accept that the president of Egypt be affiliated with Islamic movements....We are in the midst of a tremendous war against Islam". xlii According to al-Qaradāāw , the re-accession of secular rulers in Egypt represents an additional stage in the ongoing inter-religious struggle as represented by Israel, which controls America, and Islam. After the revolution, al-Sisi accused al-Qaradāwī of treason and of spying for Hamās. Al-Qaraḍāwī dismissed this and argued that this idea originated in Israel.xliii

\section{Qaraḍāwī and the civil war in Syria}

Since 2011, a bloody civil war has been raging in Syria. The Muslim Brotherhood has played an especially active role against the Alawite regime of Bashshār al-Assad. The Brotherhood and Qaraḍ̄̄ī regard victory in Syria as necessary for continuing the struggle for the liberation of Palestine. In a video interview in May 2013, al-Qaeda leader Ayman al-Zawāhiri argued that:

"The jihād against Israel is a religious obligation that all Muslims must fulfill - whether Palestinian or not. In order to achieve the liberation of Palestine, Muslims must gather in Syria and use it as a launching pad for jihād activities against Israel. When Assad's regime will be destroyed, there will be optimal conditions for the establishment of an Islamic state in Syria that will become a magnet for Muslims who will enlist in the jihād against Israel ... the jihād warriors will continue their struggle even after the fall of Assad until the liberation of all of Palestine."xliv

For many years the Muslim Brotherhood was persecuted in Syria. Several members of the Syrian ulamā were expelled and left for Qatar where they joined Qaradāwī . Syria boasts a Sunni Islamic heritage with figures such as Sāīd Hawa, Zuhair al-Shawish, Fathi Yakan, etc. According to Qaradāwī , the Sunni rebels against Assad are "men who are fighting for their homes and families and for the future of the Islamic umma".xlv Syria is just as important to the Muslims as Jerusalem and Palestine and there is a strong link between the two. Jewish pressure upon Muslims at Al-Aqșā resembles the pressure exerted by Assad upon the Muslims in Syria.xlvi Al-Qarḍāwī calls upon the entire Arab world to wake up and fight against Hezbollah and Iran in order to save their Sunni brothers. He sees Russia as playing a role in Syria similar to that of the Americans in Palestine. Russia is an infidel country supplying ammunition, tanks and advanced weaponry to Syria in order to kill Muslims.xlvii Both the Palestinians and the Syrians are unfortunate peoples who are under tyrannical rule which must be destroyed. In both cases, the answer is jiha $\bar{d}$ until the eventual victory of the believers.xlviii

After the Second Lebanon War (2006), al-Qaraḍāwī issued statements embracing Hezbollah and granting it legitimacy because of its struggle against a common enemy. Now, Hezbollah's actions in Syria are described as "criminal act[s] against the Arab nation and against Syria and against truth and justice".xlix To al-Qaradāwīi , Iran is "immoral" as it supports Bashshār Assad and is waging war with every means at its disposal - military and economic - against the poor Muslims in Syria.1 Al-Qaraḍāwī maintains that Iran is unsatisfied with its own borders and constitutes a threat to all Sunni Muslims (ahl al-Sunna). He refers to what is taking place in Syria as "slaughter." The Russians and Iranians slaughter Muslims with their weapons and "Russia blocks all foreign aid to the fighters in Syria." Assad, Russia, Hezbollah and Iran now all fall under the category of the enemies of Muslims.li

Qaradāwī says that "Whoever engages in such acts ... it is not possible to call them anything but close to the devil".lii This means that Hezbollah is not the party of God but the 
party of the devil. In another speech he argues, "How is it possible for $100,000,000$ Shiites to overcome 1,700,000,000 Sunnis?'. liii According to al-Qaradāwī , the Muslims in Syria are fighting and sacrificing themselves in order to defend their liberty. The forces of the Syrian regime and the Hezbollah are not to be regarded as Muslims but as infidels against whom one must wage war:

"Bashshār Assad does not even have a mosque or a Qurān...They do not acknowledge the principles of Islam concerning prayer and charity...Bashshār Assad separates religion from state. He does not believe in religion, does not believe in the Qur'ān and does not believe in the sunna."liv

Early in June 2013, al-Qaradāwī stated that "the Alawites are greater infidels than the Jews" lv $\mathrm{He}$ prophesized that the Islamic ruling power would be established by jihād against the Hezbollah and Iranian invasion and thus the Syrian revolution would be accomplished.lvi Al-Qaraḍāwī also came out against the sheikhs and Islamic figures who supported Assad, including Sunni Sheikh Ramadan al-Būți. Qaradāwī denies the accusations against him that he incited his followers to kill Al- Būṭîbut argues that Al- Būțī"supported the regime that killed his people." And therefore, he was murdered.lvii

As opposed to Egypt, Tunisia, Libya and Yemen, where regime change took place as a result of an awakening among the civilian population, which was partially led by the Muslim Brotherhood, a civil war continues in Syria. Qaraḍāwī uses his rhetorical skills against the Alawites, the Russian Communists, the Shiite Iranians and Hezbollah who are slaughtering the civilian Sunni population. Qaraḍ̄wī asserts that "All Muslims and all countries in the Arab and Muslim world must do all they can in order to save our Syrian brothers". lviii This message encouraged Muslim volunteers to fight against the Alawite infidels in Syria. We have the truth and we will win, says Qaraḍāwi . Victory in Syria will come. One must be patient, but eventually Islam will triumph both against the regime of the infidel Assad and against Jewish rule in Palestine.lix

\section{Conclusions}

The revolutions throughout the Arab world, especially in Egypt, Libya, Tunisia, Morocco and Yemen, showed the power of the Arab masses in pressing for regime change. Throughout 2012, al-Qaradāwī looked upon the process of the Islamization of the masses with satisfaction. For him and the leaders of the Muslim Brotherhood, it seemed as if the Syrian regime would fall momentarily. Then, after the stabilization of a single Islamic government over the Islamic umma, it would be Israel's turn to disappear from the map. While al-Qaradāwī believed that the 25/1/2011 revolution that led to Mubārak's fall was the epitome of the Arab Spring he was left with al-Sīsī's counter-revolution which overturned this successful trend.
To al-Qaraḍāwī , any Islamic religious figure in Egypt who opposed Mursi, such as Sheikh Ali Guma a, was to be regarded as an amīl (collaborator) and not as anālim (Islamic scholar).lx Al-Sīsī's counterrevolution was seen as an act of terror against a legitimate Islamic ruler and a return to a police state and a dictatorship. Ahmad al-Risuni, an expert and member of the International Union for Muslim Scholars, quotes Dr. Muhammad Amāra.lxi Despite world events -- in Tunisia the Islamic government fell apart; in Libya, the Brotherhood was unsuccessful in forming a stable coalition and in Egypt, the president, serving in the name of the Brotherhood, was dismissed. Al-Qaradāwī contends that the Islamic movement has not been defeated. Those who have patience will triumph, if not now, later on, when Allah will answer the prayers of those whom He has created.lxii

Qaradāwi feels that is a privilege to fight against rulers acting against Islam, such as al-Sīsī, who are supported by Israel and by American terror. "I stand for truth against lies and for clear justice and not for evil". lxiii

Who is to blame for the failure of the Islamic revolutions in the Arab world? To al-Qaradāwī the answer is clear. It is Israel and the United States. Representing the world view of the Muslim Brotherhood, al-Qaradāwī further views the role of Israel and of American imperialism as symbols of the enemy of Islam who plot against it in secret. The Brotherhood's website emphasizes that that it is through the Zionist lobby in the United States that Israel prevents America from taking the necessary steps against the undemocratic rule of al-S̄̄sī. lxiv Blaming Israel is something fashion like Muhammad Hasanein Heikal said once: "I wish to state out that I detest attempts to involve Israel in matters where it plays no part, only because of the desire to brandish her name in front of the masses as a scarecrow".1xv Attacks on Islam in Egypt and elsewhere, in Tunisia, Libya and Syria are led by the enemies of Islam who were surprised by the success of the believers who acted against their heretic rulers in the Arab Spring. The Democratic Pan Islamism of the Muslim Brotherhood failed. Now is the time for an even more violent Pan Islamism -- the Islamic State (ISIS).

Al-Qaraḍ̄āî 's views are a continuation of conventional ideas regarding Israel and imperialism that were popular in Egyptian Arab society during the 1950s and 60s. He continues to hold anti-Semitic views and believes and hopes that the Islamic revolutions in Arab countries, referred to as the "Arab Spring," will lead to the destruction of the State of Israel. Hamās commander memories book of 'Abd allāh Ghālib Barghūthi described the false hope of the "Arab Spring:"

"I write these words in Rimon Prison in southern Palestine, a prison close to borders of revolutionary Arab Egypt of the revolutions. I am writing after the Arab Spring that gives hope that it come like a storm against the Zionists."lxvi

All what happened in the Arab World according to al-Qaradāwī is part of religious war. "Every battle that a 
Muslim enters into to defend rightness, resist falsehood, establish justice, or revolt against oppression is a religious battle because it is a battle in the cause of God."lxvii The Israeli motive to block the Muslim Brotherhood is clear. According to the Hamās activist Khālid AbūArfa, Hamās members, and other Islamic thinkers the Israel-American conspiracy is the reason why the "Arab Spring" failed.

\section{REFERENCES}

[1] Abū Arfa , Khaled, Thawrāt Tudhin bi-Fajr Jadīd-Nazrāat Fiqhiyya, (Jerusalem, no publisher listed, 2011).

[2] Ali, Ahmad, "al-Qaraḍ̂̄wī : Mundhu majii Ila Qațar lam uayyid hakiman zaliman" ("Al-Qaraḍāwī : Since I arrived in Qatar, I definitely did not support the Evil Regime"), Al-Qarad̄̄ōi Website, 24/12/2013, http://www.Qaraḍ̄āī .net/news/7064-2013-12-23-11-11-47. html

[3] Al-Qarad̄̄wī , Yusūf, Dars al-Nakbah al-Thaniyah: Li-Madha Inhazamna-- Wa-Kayfa Nantasir (Cairo: Maktabat Wahbah, 1993).

[4] Al-Qaraḍ̄̄̄ī , Yusūf, Ibn al-Qarya wa-al-Kuttab (Cairo, Dar al-Sharuq, 2002).

[5] Al-Qaraḍāwī , Yusūf, "al-Ișyān Marfūọ Tamama wal-Misriyun Mutalibun B'aamal Allah B'aamalhoum" [We must totally reject the revolt: The Egyptians must dedicate themselves to worshipping the creator through their deeds], Qaradāwī website, 9/2/2012.

http://www.Qarad̄āwī .net/news/5560-2012-02-10-12-41-56. html

[6] Al-Qaraḍāwī , Yusūf, "Istiftāal-Inqilāb bātil" [The Plebiscite of the Revolution Has Been Cancelled], Qara $\mathbf{d} \bar{a} w \bar{\imath}$ Website, 21/1/2014, http://www.Qaradāwī .net/news/7113-2 014-01-20-04-42-21.html.

[7] Al-Rai (Qatar), 10/10/2009, quoted from: "The Palestinian Authority Attacks Qaradāwī against the Background of His Call to Stone Mahmoud Habash," MEMRI Website, $25 / 3 / 2010$,

http://www.memri.org.il/cgi-webaxy/sal/sal/pl?lang=he\&lD $=107345$ memri\&act $=$ show $\&$ dbid $=$ articles \&dataaid $=2330$

[8] Al-Sharīa wal-Hayāt, Hudūd Allah, Al-Jazeera, 2/6/2013, https://www.youtube.com/watch?v=cX7C3OkYzQ0.

[9] Al- sharīa wal-Hayāt, Liqā khațir ma al-Sheikh Yusūf al-Qaraḍ̄wī Hawl Ahadīth al-fitan wa-isqātiha ala al-Waqi (An important speech by Sheikh Yusūf Al-Qaradāwī concerning the events of the riots and their influence upon the situation], Al-Jazeera, 9 June 2013, http://www.youtube.com/watch?v=YGYlmwV6Sog

[10] Al-Sharīa wal-Hayāt, al-Khawārij bayn al-Dīn wal-Tarkīh wal-Siyāsa, Al-Jazeera, 25//8/ 2013,

$\mathrm{http}: / / \mathrm{www}$.youtube.com/watch? $\mathrm{v}=\mathrm{V} 12 \mathrm{zCzozumQ}$

[11] Bargouti, Abdullah Ghaleb, Muhadis ala al-Tarīq-Amir al-Zill (Dar Al-Bargouti Lanshar wa-al-Toziya, 2013).

[12] Baroudi Sami E., "Sheikh Yusūf Qarad̄āwī on International Relations: The Discourse of a Leading Islamist Scholar
(1926-)", Journal of Middle Eastern Studies, Vol. 50, 2014, pp. 2-26.

[13] Gershoni, Israel, Tehiyat Ha-Islam ke-Manof le-Aliyat ha-Arviyut:Ha-Salafiya ha-Mitzrit ve-Tesmihat ha-Arviyut be-Mitzrayim ha-Kdam Mahapkhanit, (Hebrew) (Tel-Aviv: Tel Aviv University Press, 1979).

[14] Gold, Dore, Hatred's Kingdom: How Saudi Arabia Supports the New Global Terrorism (Washington, D.C.: Regnery, 2003).

[15] Harel, Amos, "The Civil War in Syria Saved al-Qaeda," Haaretz, 1/13/2014, http://www.haaretz.co.il/news/politics/.premium-1.2215290 (Hebrew).

[16] Ismail, Samir, Al-Lūbi al-Șahyūni yadu Washintun li-Istimrār dam al-Inqilab al-Askari [The Zionist Lobby Has Informed Washington to Continue and Support the Military Coup], Muslim Brotherhood Website, 2/8/2013, http://www.ikhwanonline.com/Article.aspx?ArtlD=158773\& $\mathrm{Sec} 1 \mathrm{D}=341$

[17] Kedar, Mordecai, "Hurray for Sisi," Makor Rishon, no. 857, Yoman, 10/1/2014, pp. 19-20. (Hebrew).

[18] Khouri, Jacky, "Final Results in Egypt: 70\% for Islamic Parties," Haaretz, 21/1/2012. http://www.haaretz.co.il/news/ world/middle-east/1.622481.

[19] Kramer, Gudrun, "Drawing Boundaries, Yusūf al-Qaradāwī on Apostasy," in, Gudrun Kramer and Sabine Schmidtke (ed.), Speaking for Islam, Religious Authorities in Muslim Societies (Leiden, 2006).

[20] Quțb, Sayyid, Marakatuna ma al-Yahūd (Cairo: Dar Al-Sharuq, 1993)

[21] Quṭb, Sayyid, Maālim fil-Ṭarīq (Gaza: Hamās Publishers, 2004)

[22] Quțb, Sayyid, Milestones (Ma'alim fi'l Tareeq) [sic], ed., A-B al-Mehri (Birmingham, England: Maktabah Booksellers and Publishers, 2006).

[23] Ramadan, Madhat, "Al-Alāma al-Qaraḍ̂̄wī al-Khurūj ḍid al-Inqilāb Wajeb Shar'ai wa-al-Qoutla Shuada bi-Ouzen Allah" (The religious figure Qaraḍāwi : opposing the revolution is a religious obligation and the dead are Shahids according to God), Muslim Brotherhood website, 2/1/2014, http://www.ikhwanonline.com/Article.aspx?ArtID=174828 $\& \mathrm{SecID}=230$.

[24] Sivan, Emmanuel, Kanaei Ha-Islam (Tel Aviv: Am Oved, 1994).

[25] Singh Rashmi, Hamās and Suicide Terrorism (New York: Routledge, 2012).

[26] Tammam, Husan, "Yusūf Qaradāwī and the Muslim Brothers: The Nature of a Special Relationship, in: Bettina Graf and Jacob Skovgaard-Petersen, Global Mufti: The Phenomenon of Yusūf al-Qarad̄̄ōi (New York: Columbia University Press, 2009).

[27] The Daily News Egypt," 30 "Al-Qaraḍāwī Returns to Egypt from Qatar,” June 2013, http://www.dailynewsegypt.com/2013/06/30/al-Qaradāwī -returns-to-egypt-from-qatar 
[28] Volker. H., Green, R, and Barkan, L, "Following Hezbollah's announcement that It is fighting in Syria: calls to Sunni Muslims for Jihād against Hezbollah and the
Shiites,"
MEMRI
Website,
$7 / 6 / 2013$
http://www.memri.org.il/cgi-webaxy/sal/sal.pl?lang=he\&1D $=107345$ _memri\&act $=$ show $\&$ dbid=articles $\&$ dataaid $=3405$

i Yusuf Al-Qaradawi, [4], pp. 51-57.

ii Sayyid, Qutb [22], p.91. Sayyid Qutb, [21], p. 92.

iii Sayyid Qutb, [22], ch. 5, p. 93; Arabic text, [21].pp 93-94.

iv Sayyid Qutb, [20], pp. 13-14.

$\mathrm{v}$ [10].

vi Gudrun Kramer, [19] pp. 204-205; Emmanuel Sivan, [24], pp. 100-103

(Hebrew).

vii Ahmad Ali [2].

viii [7].

ix This view contradicts the position of Husan Tammam who tries to present Qaradawi as an opponent of the idea of takfir. Husan Tammam, [26], pp. 70-71.

x Sami E., Baroudi, [12], p. 9.

xi See: Ahmad Ali, [2],

xii Gudrun Kramer, [19], pp. 212-213.

xiii Singh Rashmi, [25], p. 99.

xiv Khaled Abu Arfa, [1], p. 16

xv Emmanuel Sivan, [24], pp. 100-103. The arguments of Qaradawi and of

Qutb are based on the writings of Ibn Tamiyya regarding the right to rebel against a tyrannical ruler.

xvi Gudrun Kramer, [19] pp. 212-213.

xvii Al-sharīa wal-Hayāt, [8].

xviii Dore Gold, [14], pp. 55, 74-75, 92-94

xix See: Al-sharīa wal-Hayāt, [8]

xx Ibid.

xxi Al-Aqsa Channel (Gaza) 10 May 2013, http://aqsatv.ps.

xxii Israel Gershoni, [13], p. 79

xxiii Yusuf al-Qaradawi, [3], p. 40

xxiv Husan Tammam, [26], pp. 64-65.

xxv Khaled Abu Arfa, [1], p. 20.

xxvi Ibid.

xxvii Ibid., p. 21

xxviii Ibid.

xxix Jacky Khouri, [18]. 2012.

xxx Yusuf al-Qaradawi, [5]

xxxi Ibid.

xxxii Al-sharīa wal-Hayāt, [10]

xxxiii Ibid.

xxxiv Khaled Abu Arfa, [1], pp. 7-8.

xxxv "Al-Qaradawi Returns to Egypt from Qatar, [27]

xxxvi Al- sharīa wal-Hayāt, [5]

xxxvii Quoted by Dr. Mordecai Kedar, [17]

xxxviii Madhat Ramadan, [23]

xxxix Ibid.

xl Ibid.

xli Ibid.

xlii Al-Qaradawi,[6]

xliii Ahmad Ali, [2]

xliv Amos Harel, [15]

xlv Al-sharīa wal-Hayāt, [8]

xlvi Al-sharia wal-Hayāt, [9]

xlvii Ibid.

xlviii Al-Aqsa Channel, Gaza, 10 May 2013, http://aqsatvps Qaradawi's sermon at the Al-Amri Mosque in Gaza.

xlix Al-sharīa wal-Hayāt, [8]

1 Al-sharīa wal-Hayāt, [9]

li Al-sharīa wal-Hayāt, [8]

lii Ibid.

liii H. Volker, R. Green, L. Barkan, [28]

liv Al-sharīa wal-Hayāt, $[9]$

lv Al-Rai (Qatar), i June 2013

lvi Al-sharīa wal-Hayāt, [8]

lvii Ahmad Ali, [2]

lviii Al-sharīa wal-Hayāt,[9]

lix Ibid.

lx Al-sharīa wal-Hayāt, [10]

lxi Al-sharīa wal-Hayāt, [8]

lxii Ahmad Ali,[2]

lxiii Ibid.

lxiv Samir Ismail, [16]

lxv Al-Ahram, 21 December, 1962

lxvi Abdullah Ghaleb Barghouti, [11], p. 147

lxvii Sami E., Baroudi, [12], p.13. 